\title{
Inhibitory effects of sulphur compounds, copper and tungsten on nitrate reduction by mixed rumen micro-organisms
}

\author{
BY JUNICHI TAKAHASHI, NOBUYUKI JOHCHI \\ AND HIROSHI FUJITA \\ Department of Animal Science, Obihiro University of Agriculture and Veterinary \\ Medicine, Obihiro, Japan 080
}

(Received 20 September 1988 - Accepted 20 December 1988)

1. The inhibitory effects of inorganic and organic sulphur-containing compounds, copper and tungsten on nitrate reduction by mixed rumen micro-organisms were investigated in two in vitro studies.

2. Coarsely strained rumen fluid from nitrate-adapted (Expt 1) or non-adapted (Expt 2) Suffolk Down wethers maintained on lucerne (Medicago sativa) cubes was used as an inoculum. In Expt 1, anaerobic incubation was carried out for $24 \mathrm{~h}$ for each medium supplemented with $10 \mathrm{~mm}$-sodium nitrate and the following chemicals: 0,1 , 2, 3, 5, 8 and $10 \mathrm{~mm}$-sodium sulphide, 1 and $10 \mathrm{~mm}$-sodium sulphite, 1 and $10 \mathrm{~mm}$-sodium sulphate, 1 and $10 \mathrm{~mm}-$ L-cysteine, 1 and $10 \mathrm{~mm}$-DL-methionine, $1 \mathrm{~mm}$-sodium tungstate and $1 \mathrm{~mm}$-copper sulphate. In Expt 2,1 and 10 mM- $\mathrm{Na}_{2} \mathrm{~S}, 1$ and $10 \mathrm{~mm}-\mathrm{L}$-cysteine, $1 \mathrm{~mm}-\mathrm{Na}_{2} \mathrm{WO}_{4}$, and $1 \mathrm{~mm}-\mathrm{CuSO}_{4}$ were added to incubation media to test for chemical inhibition of microbial reduction of nitrate.

3. In Expt 1, the amount of nitrite formed decreased with increasing concentration of sulphide-S added. The additions of $\mathrm{L}$-cysteine, $\mathrm{W}$ and $\mathrm{Cu}$ suppressed nitrite formation in media from both nitrate-adapted and nonadapted sheep.

4. In contrast to the effects of sulphide, L-cysteine and $W$ counteracted, to some degree, nitrate-induced reduction of volatile fatty acid (VFA) production. Addition of $\mathrm{Cu}$ to the media resulted in a further depression of VFA production.

Enzymic reduction of nitrate is classified into two types depending on the metabolic function (Payne, 1973). In nitrate-respirating and denitrifying species of bacteria, classified into genera such as Escherichia, Proteus, Paracoccus and Pseudomonas, the reducing pathways of nitrate have been demonstrated as being dissimilar. Rumen bacteria, in contrast, are assumed to reduce nitrate in an assimilative manner, as do plant cells and fungi (Prins et al. 1980). In any event nitrate must be reduced primarily to nitrite, and the nitrate reductase (nitrate reductase $(\mathrm{NADPH}) ; E C$ 1.6.6.3) involved in the reaction step is known to be a molybdo-enzyme (Nason \& Evans, 1953; Hewitt, 1975). The reducing step is of primary importance to the incidence of nitrate-nitrite poisoning in ruminant animals. The nitrate reduction in rumen bacteria has been reported to be inhibited by tungstate and promoted by molybdate (Tillman et al. 1965; Korzeniowski et al. 1980, 1981 ; Prins et al. 1980; Marais et al. 1988), as is nitrate reductase derived from other ecosystems (Seki-Chiba \& Ishimoto, 1977; Oltmann et al. 1979; Burke et al. 1980; Aslam, 1982; Shen et al. 1982; Tachiki \& Nason, 1983; Deaton et al. 1984; Saracino et al. 1986). In addition, it has been proposed that an inorganic combination of molybdenum and copper or sulphur, or $\mathrm{Mo}+\mathrm{Cu}+\mathrm{S}$, results in the formation of an insoluble complex salt (Grace \& Suttle, 1979; Ammerman \& Goodrich, 1983) and it is, therefore, possible that $\mathrm{Cu}$ and $\mathrm{S}$ may inhibit nitrate reductase. $\mathrm{Cu}$ is an essential trace element for ruminant nutrition, but its maximum requirement is extremely small (National Research Council, 1988). Both $\mathrm{Cu}$ and W may be of minor importance for practical applications as inhibitors against nitrate-nitrite poisoning in ruminants due to their toxic properties. However, it seems that $\mathrm{Cu}, \mathrm{W}$ and $\mathrm{S}$ can be useful elements in finding clues to the possible participation of Mo in the activation of nitrate reductase in rumen microbial populations. In establishing a natural prophylactic for nitrate hazards in animal production, application of S-containing compounds is 
valuable, because $S$ is a major element present in several essential amino acids and in the biologically active tripeptide, glutathione, which plays an important part in non-enzymic reduction of erythrocyte methaemoglobin (Takahashi, 1983).

The present paper deals with the inhibitory effects of $\mathrm{S}$ compounds, $\mathrm{Cu}$ and $\mathrm{W}$ on in vitro nitrate reduction by rumen micro-organisms.

\section{MATERIALS AND METHODS}

\section{Experimental procedures}

Eight rumen-fistulated Suffolk Down wethers, maintained on lucerne (Medicago sativa) cubes $\left(50 \mathrm{~g}\right.$ dry matter $/ \mathrm{kg}$ body-weight ${ }^{0.75}$ per d) were randomly allocated in equal numbers to two in vitro experiments. To obtain rumen fluid containing nitrate-adapted microbial populations, each animal was given $0.55 \mathrm{~g}$ sodium nitrate $/ \mathrm{kg}$ body-weight $\mathrm{t}^{0.75}$ twice daily for 35 d via a fistula. Rumen fluid from each nitrate-adapted (for Expt 1) or non-adapted (for Expt 2) sheep was pooled and strained through four layers of muslin cloth. Strained fluid ( 1 vol.) was then added to 4 vol. preheated $\left(38^{\circ}\right)$, buffered mineral salts solution (McDougall, 1948) containing $10 \mathrm{~mm}-\mathrm{NaNO}_{3}, 10 \mathrm{~mm}$-glucose and $40 \mathrm{~mm}$-lactate, with or without various amounts of the potential chemical inhibitors under investigation. The suspensions were mixed under an atmosphere of carbon dioxide, and $50 \mathrm{ml}$ portions were added to autoclaved incubation vessels stoppered with one-way Bunsen gas-release valves to maintain anaerobic conditions. Five vessels per treatment were assigned randomly and placed in a water-bath at $38^{\circ}$. The incubation was carried out anaerobically at $38^{\circ}$ for 24 h.

Expt 1. To test the inhibitory effects of inorganic and organic $\mathrm{S}$ compounds, $\mathrm{W}$ and $\mathrm{Cu}$ on nitrate reduction by the rumen microbial populations adapted to nitrate, the following compounds were put into separate incubation vessels: sulphide $(1,2,3,5,8$ and $10 \mathrm{mM}^{-\mathrm{Na}_{2}} \mathrm{~S} .9 \mathrm{H}_{2} \mathrm{O}$ ), sulphite ( 1 and $10 \mathrm{mM}-\mathrm{Na}_{2} \mathrm{SO}_{3}$ ), sulphate (1 and $10 \mathrm{~mm}-\mathrm{Na}_{2} \mathrm{SO}_{4}$ ), Lcysteine ( 1 and $10 \mathrm{mM})$, DL-methionine ( 1 and $10 \mathrm{mM})$, tungstate $\left(1 \mathrm{~mm}-\mathrm{Na}_{2} \mathrm{WO}_{4} \cdot 2 \mathrm{H}_{2} \mathrm{O}\right)$ or $\mathrm{Cu}$ salt $\left(1 \mathrm{~mm}-\mathrm{CuSO}_{4} \cdot 5 \mathrm{H}_{2} \mathrm{O}\right)$. After $24 \mathrm{~h}$ incubation, portions of culture media were collected for nitrite determination.

Expt 2. To test direct effects of the inhibitors on nitrate reduction in non-adapted microbial populations, the anaerobic incubation was carried out for $24 \mathrm{~h}$ with or without

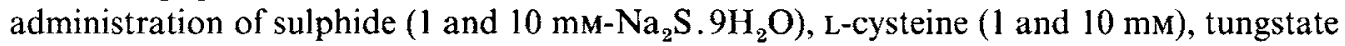
( $1 \mathrm{~mm}-\mathrm{Na}_{2} \mathrm{WO}_{4} \cdot 2 \mathrm{H}_{2} \mathrm{O}$ ) or copper salt $\left(1 \mathrm{mM}^{-\mathrm{CuSO}} \mathrm{S}_{4} \cdot 5 \mathrm{H}_{2} \mathrm{O}\right)$. After $24 \mathrm{~h}$ incubation, nitrite in each incubation medium was determined as described in Expt 1.

\section{Analytical procedures}

According to the method described by Prins et al. (1980), $1 \mathrm{ml}$ of each culture medium was deproteinized and diluted by the addition of $3 \mathrm{ml}$ lead acetate $(50 \mathrm{~g} / \mathrm{l})$ and $1 \mathrm{ml}$ of a saturated $\mathrm{Na}_{3} \mathrm{PO}_{4} \cdot 12 \mathrm{H}_{2} \mathrm{O}$ solution. Nitrite contents were determined colorimetrically by the diazo-coupling method (Horwitz, 1975). The concentrations of volatile fatty acids (VFA) in the media were determined using a gas-liquid chromatograph (GC-3BF; Shimazu) equipped with a flame-ionization detector. The sample mixture was mixed well and centrifuged at $8000 \mathrm{~g}$ for $15 \mathrm{~min}$. After centrifugation, $2 \mathrm{ml} 50 \mathrm{~mm}$-crotonic acid was added as internal standard (Stanier \& Davies, 1981) to $2 \mathrm{ml}$ of the supernatant fraction followed by acidification with $0.05 \mathrm{ml} 6 \mathrm{M}$-sulphuric acid. The mixture was injected into a glass column $(1.7 \mathrm{~m} \times 3.0 \mathrm{~mm})$ packed with $10 \%$ polyethylene glycol (molecular weight 6000 ) coated on TPA (30-60 mesh). The column was operated at $145^{\circ}$ with high purity nitrogen as the carrier gas. The values were processed automatically using a Chromatopac data processing system (C-R 3A; Shimazu). 


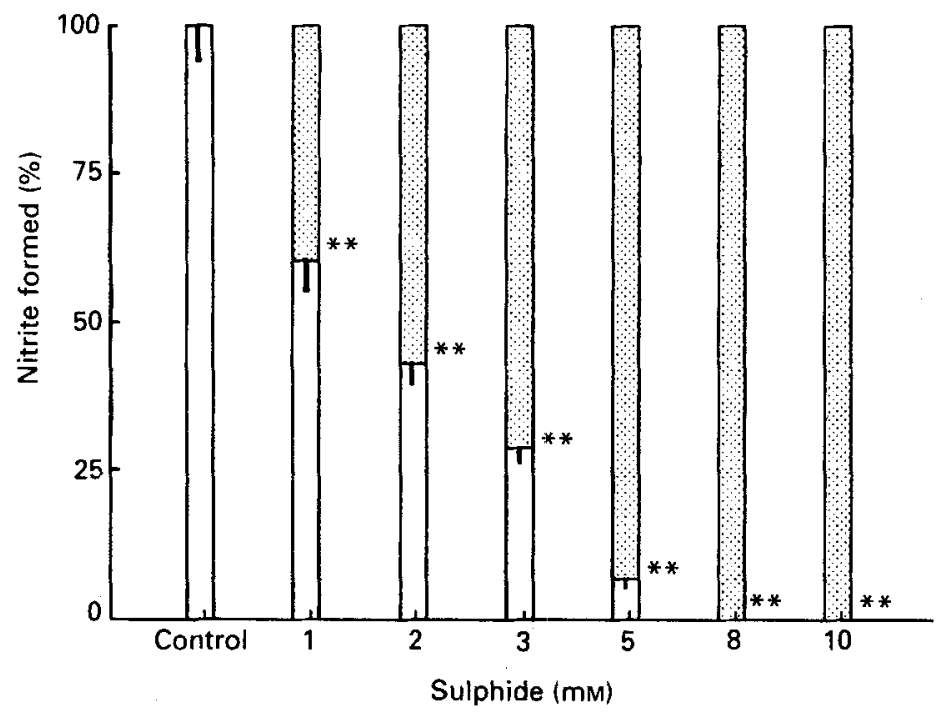

Fig. 1. Effect of sulphide-sulphur on nitrite formation in rumen fluid containing microbial populations adapted to nitrate. Values are means for five determinations with their standard errors represented by vertical bars. ( $\square$ ), Relative amount of nitrite formed (control value indicates 103.20 (SE 5.76) $\mu \mathrm{g}$ nitrogen $/ \mathrm{ml}$ ); (国), relative amount of nitrite suppressed ; ${ }^{* *} P<0.01$.

\section{Statistical analysis}

The statistical significance of the difference between the means of control and treatments was assessed by analysis of variance.

\section{RESULTS}

Effects of $S$ compounds, $C u$ and $W$ on nitrate reduction in vitro

Expt 1. Fig. 1 shows the effect of sulphide-S on nitrite formation in rumen fluid containing microbial populations adapted to nitrate. A marked inhibition of nitrite formation was observed in rumen microbial populations adapted to nitrate as increasing amounts of sulphide-S were added. The addition of $5 \mathrm{~mm}$-sulphide decreased nitrite formation by up to $90 \%$. The addition of more than $8 \mathrm{~mm}$-sulphide completely suppressed nitrite formation by rumen microbes in vitro.

Fig. 2 shows the degree of suppression of nitrite formation from nitrate attributable to inorganic and organic $S$, and the transition metals tested. Neither sulphate-S nor sulphite$\mathrm{S}$ affected nitrite formation. Of the S-containing amino acids, DL-methionine proved to be inefficient in inhibiting microbial reduction of nitrate. The addition of L-cysteine to the medium, however, significantly $(P<0.01)$ lowered nitrite formation, with an evident dosedependent effect. The extent of the depression of nitrite formation was $50 \%$ at $1 \mathrm{mM}-\mathrm{L}-$ cysteine $(P<0.01)$ and $100 \%$ at $10 \mathrm{~mm}-\mathrm{L}-$ cysteine $(P<0.01)$. The metals $\mathrm{W}$ and $\mathrm{Cu}$ both significantly $(P<0.01)$ reduced nitrite formation after $24 \mathrm{~h}$ incubation.

Expt 2. Fig. 3 shows inhibitory effects of sulphide, L-cysteine, tungstate and $\mathrm{Cu}$ salts on nitrite formation by rumen microbial populations not adapted to nitrate. All chemicals added, except tungstate, showed approximately the same magnitude of inhibition of nitrite formation for both nitrate-adapted (Expt 1) and non-adapted organisms (Expt 2). 


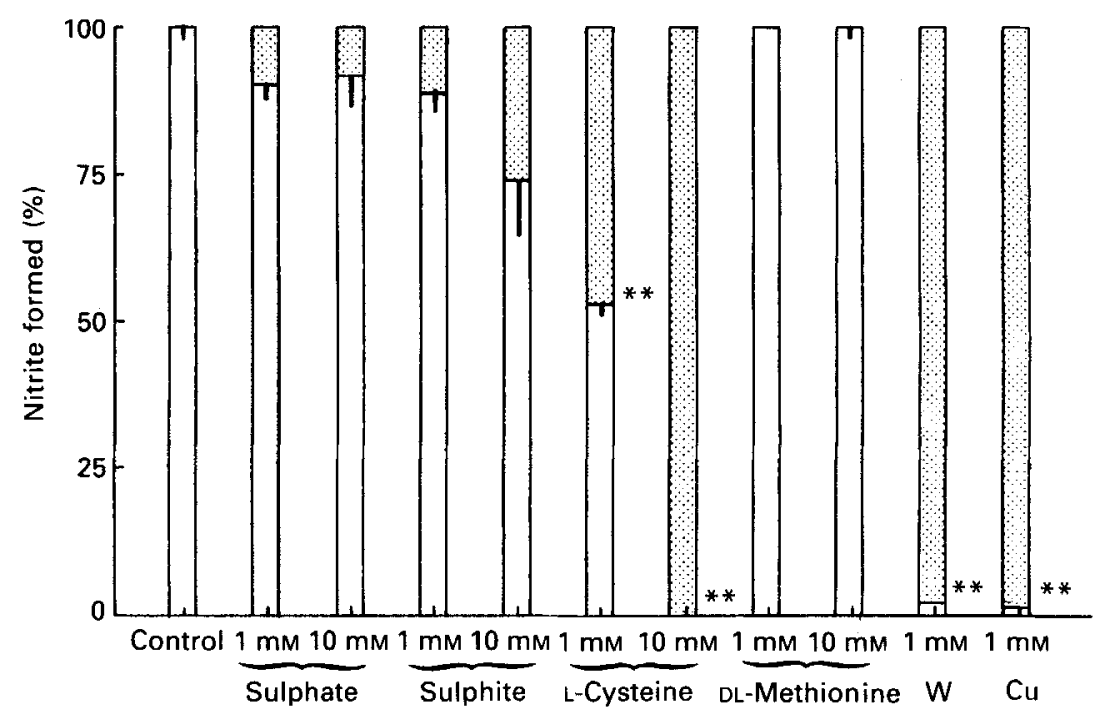

Fig. 2. Effects of inorganic and organic sulphur, tungsten and copper on nitrite formation in rumen fluid containing microbial populations adapted to nitrate. Values are means for five determinations with their standard errors represented by vertical bars. ( $\square$ ), Relative amount of nitrite formed (control value indicates $106.00(\mathrm{SE} 2 \cdot 12) \mu \mathrm{g}$ nitrogen $/ \mathrm{ml}$ ); (国), relative amount of nitrite suppressed; ${ }^{* *} P<0 \cdot 01$.

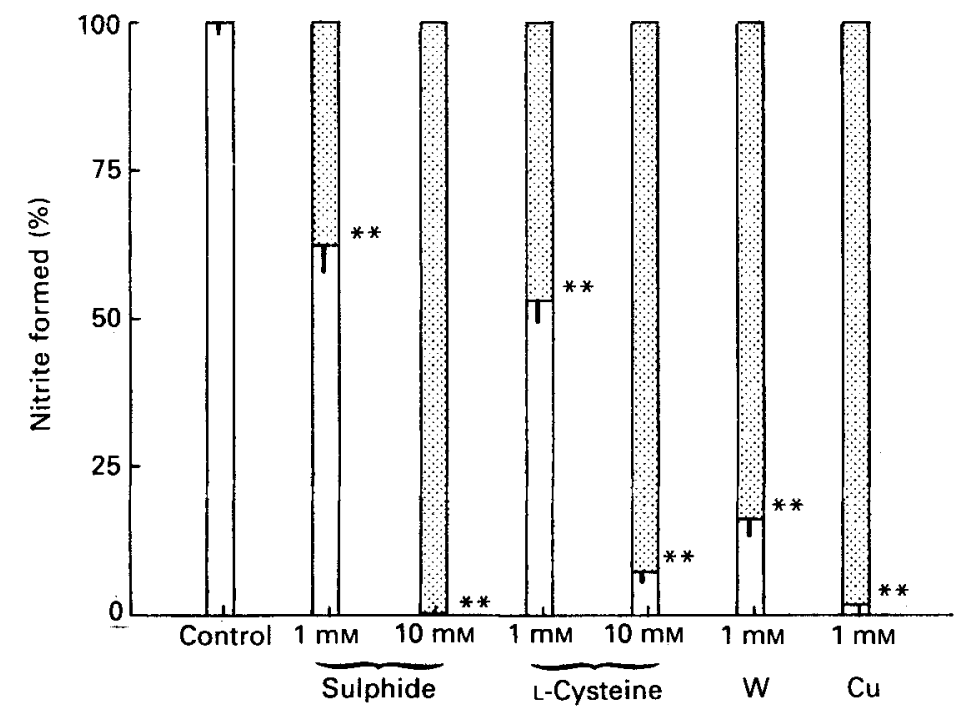

Fig. 3. Effects of sulphide, L-cysteine, tungsten and copper on nitrite formation by rumen microbial populations not adapted to nitrate. Values are means for five determinations with their standard errors represented by vertical bars. ( $\square$ ), Relative amount of nitrite formed (control value indicates 69.81 (SE 1.59) $\mu \mathrm{g}$ nitrogen $/ \mathrm{ml}$ ); (因), relative amount of nitrite suppressed; ** $P<0.01$.

\section{Effects of $S$ compounds, $\mathrm{Cu}$ and $\mathrm{W}$ on VFA production in the presence of nitrate}

The effects of S compounds, W and Cu on VFA production by nitrate-adapted (Expt 1) and non-adapted (Expt 2) organisms in the presence of nitrate are summarized in Table 1. Results show that sulphide, L-cysteine and $\mathrm{W}$ can be efficient in suppressing nitrite 
Sulphur and nitrate reduction

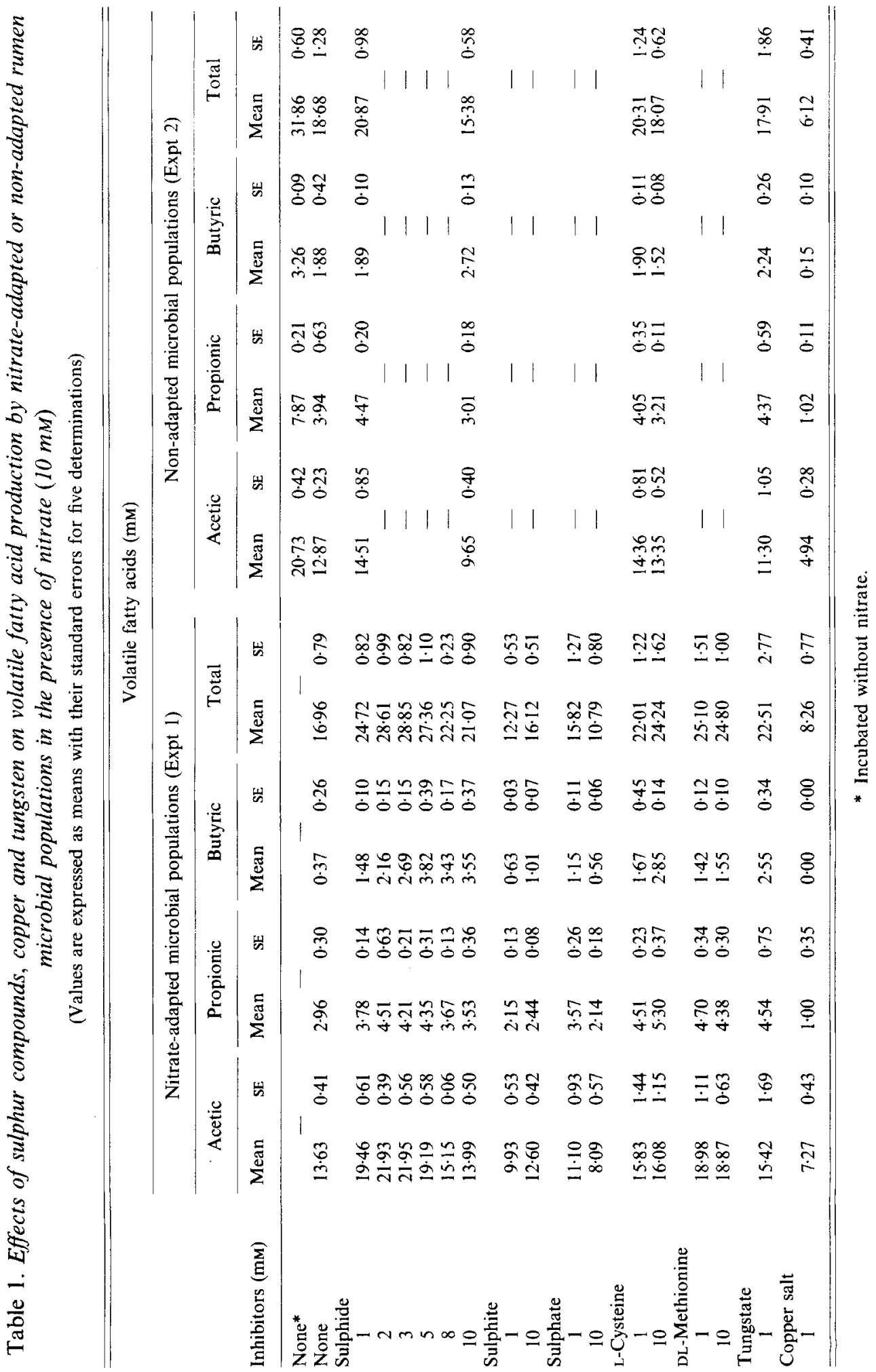


formation, and also overcome the decrease in total contents and the change in molar ratios of VFA caused by nitrate.

\section{DISCUSSION}

Mo is a metal of the second transition series, an essential component of nitrate reductase. Tungsten, an element homologous to Mo, competes with Mo. Thus, nitrate reductases of various origins are inhibited by $\mathrm{W}$, as are other molybdo-enzymes (Johnson et al. 1974a, $b$ ). The significant depressing effect of $\mathrm{W}$ on nitrite formation by mixed nitrate-adapted rumen microbes (prepared by straining rumen fluid) observed in the present work is in good agreement with other reports of in vitro experiments (Prins et al. 1980; Marais et al. 1988). However, a smaller suppression of nitrite formation by $\mathrm{W}$ was observed with non-adapted microbial populations. In in vitro experiments using inocula from both nitrate-adapted and non-adapted cows, higher sensitivity of nitrite formation to $\mathrm{W}$ inhibition has been reported with nitrate-adapted organisms (Prins et al. 1980). Additionally, the magnitude of the inhibitory effect of $\mathrm{W}$ on rumen formation of nitrite varies with the feeding regimens of the host animals and with substrates used as energy sources for the incubation (Prins et al. 1980). The inhibitory effect of $W$ on nitrite formation may be primarily dependent on the ratio, free Mo ions : native molecules of nitrate reductase in rumen fluid.

The interactions between $\mathrm{Mo}$ and $\mathrm{Cu}$, and the formation of insoluble copper thiomolybdate, probably inhibit nitrate reductase in rumen micro-organisms. The dietary requirement and physiologically tolerable amount of $\mathrm{Cu}$ for ruminants depends on dietary $\mathrm{S}$ and Mo (National Research Council, 1988). However, adverse effects of more than $1 \mu \mathrm{g}$ $\mathrm{Cu} / \mathrm{ml}$ in the rumen fluid on cellulose digestion by rumen micro-organisms have been reported (Martinez \& Church, 1970). The effect of $\mathrm{Cu}$ toxicity on VFA production (Table 1) suggests that bacteriostasis caused by this element cannot be denied, due to its inhibitory effect on nitrate reduction (Figs 2 and 3). Apart from the digestive crises in the rumen, possible problems relating to the health of animals and man and environmental contamination remain to be clarified before these transition metals are used as prophylactics against nitrate-nitrite poisoning in ruminants.

In in vivo physiological concentrations ( $<1 \mathrm{~mm}$-sulphide), sulphide absorption may be extremely rapid (Bray \& Till, 1975). Consequently, undissociated sulphide can be directly absorbed across the rumen epithelium, although the turnover rate is variable depending on the $\mathrm{N}: \mathrm{S}$ ratio in the rumen. It is probable that the undissociated sulphydryl ions or $\mathrm{H}_{2} \mathrm{~S}$ absorbed from the rumen can become a metabolic poison for the animal due to sulphide overdose. In terms of partial recovery of VFA production reduced by nitrate (Table 1), it is unlikely that the sulphide added, even at $10 \mathrm{~mm}$, adversely affected microbial fermentation in vitro. Therefore, a marked depression in nitrite formation by the addition of sulphide indicates that elemental $\mathbf{S}$ degraded from sulphide inhibits the activity of nitrate reductase as a result of interference with the incorporation of Mo into the enzyme. In an early study of nitrate reductase in wild type Neurospora crassa (5297a), Nason \& Evans (1953) observed that the -SH group played a significant part in the stability of this enzyme, and demonstrated small inhibitory effects on the enzyme activity at a higher concentration (1 $\mathrm{mm}$ ) of L-cysteine. Although the in situ participation of the $-\mathrm{SH}$ group in the activity and de novo synthesis of nitrate reductase (Azoulay et al. 1969) cannot be ruled out in the present work, it seems reasonable to assume that the sulphide-S generated from L-cysteine by the L-cysteine hydrogen sulphide-lyase (cystathionine $\gamma$-lyase; $E C 4.4 .1 .1$ ) reaction (Collins \& Monty, 1973) of rumen bacterial origin interferes with the nitrate reduction. Currently, interference of undegraded $\mathrm{S}$ in nitrate reductase activity from rumen microbial origin has not been established. 
Therefore, the significant suppressing effect of L-cysteine on nitrite formation by rumen microbes is of particular interest when considering the dietary control of the hazards of nitrate to livestock.

\section{REFERENCES}

Ammerman, C. B. \& Goodrich, R. D. (1983). Advances in mineral nutrition in ruminants. Journal of Animal Science 57, 519-533.

Aslam, M. (1982). Differential effect of tungsten on the development of endogenous and nitrate-induced nitrate reductase activities in soybean leaves. Plant Physiology 70, 35-38.

Azoulay, E., Puig, J. \& Martins Rosado De Sousa, M. L. (1969). Regulation de la synthese de la nitrate-reductase chez Escherichia coli K 12. Annales de l'Institute Pasteur, Paris 117, 474-485.

Bray, A. C. \& Till, A. R. (1975). Metabolism of sulphur in the gastro-intestinal tract. In Digestion and Metabolism in the Ruminant, pp. 243-260 [I. W. McDonald and A. C. I. Warner, editors]. Sydney: University of New England Publishing Unit.

Burke, K. A., Calder, K. \& Lascelles, J. (1980). Effects of molybdenum and tungsten on induction of nitrate reductase and formate dehydrogenase in wild type and mutant Paracoccus denitrificans. Archives of Microbiology 126, $155-159$

Collins, J. M. \& Monty, K. J. (1973). The cysteine desulfhydrase of Salmonella typhimurium. Journal of Biological Chemistry 248, 5943-5949.

Deaton, J. C., Solomon, E. I., Durfor, C. N., Wetherbee, P. J., Burgess, B. K. \& Jacobs, D. B. (1984). Activation of nit- 1 nitrate reductase by $\omega$-formate dehydrogenase. Biochemical and Biophysical Research Communications 121, 1042-1047.

Grace, N. D. \& Suttle, N. F. (1979). Some effects of sulphur intake on molybdenum metabolism in sheep. British Journal of Nutrition 41, 125-136.

Hewitt, E. J. (1975). Assimilatory nitrate-nitrite reduction. Annual Review of Plant Physiology 26, $73-100$.

Horwitz, W. (1975). Official Methods of Analysis of the Association of Official Analytical Chemists, 12 th ed. Washington, DC: Association of Official Analytical Chemists.

Johnson, J. L., Cohen, H. J. \& Pajagopalan, K. V. (1974a). Molecular basis of the biological function of molybdenum. Molybdeum-free sulfite oxidase from livers of tungsten-treated rats. Journal of Biological Chemistry 249, 5046-5055.

Johnson, J. L., Waud, W. R., Cohen, H. J. \& Pajagopalan, K. V. (1974b). Molecular basis of the biological function of molybdenum. Molybdenum-free xanthine oxidase from livers of tungsten-treated rats. Journal of Biological Chemistry 249, 5056-5061.

Korzeniowski, A., Geurink, J. H. \& Kemp, A. (1980). Nitrate poisoning in cattle. 5. The effect of tungstate on nitrite formation by rumen microbes. Netherland Journal of Agricultural Science 28, 16 19.

Korzeniowski, A., Geurink, J. H. \& Kemp, A. (1981). Nitrate poisoning in cattle. 6. Tungsten (wolfram) as a prophylactic against nitrate-nitrite intoxication in ruminants. Netherland Journal of Agricultural Science 29 , $37-47$.

McDougall, E. I. (1948). Studies on ruminant saliva. 1. The composition and output of sheep's saliva. Biochemical Journal 43, 99-109.

Marais, J. P., Therion, J. J., Mackie, R. I., Kistner, A. \& Dennison, C. D. (1988). Effect of nitrate and its reduction products on the growth and activity of the rumen microbial population. British Journal of Nutrition 59, 301-313

Martinez, A. \& Church, D. C. (1970). Effect of various mineral elements on in vitro rumen cellulose digestion. Journal of Animal Science 31, 982-990.

Nason, A. \& Evans, H.J. (1953). Triphosphopyridine nucleotide-nitrate reductase in Neurospora. Journal of Biological Chemistry 202, 655-673.

National Research Council (1988). Nutrient Requirements of Dairy Cattle, 6th ed. Washington, DC: National Academy Press.

Oltmann, L. F., Claassen, V. P., Kastelein, P., Reijnders, W. N. M. \& Stouthamar, A. H. (1979). Influence of tungstate on the formation and activities of four reductases in Proteus mirabilis. FEBS Letters 106, 4346.

Payne, W. J. (1973). Reduction of nitrogenous oxides by microorganisms. Bacteriological Reviews 37, 409-452.

Prins, R. A., Cline-Theil, W., Malestein, A. \& Counotte, G. H. M. (1980). Inhibition of nitrate reduction in some rumen bacteria by tungstate. Applied and Environmental Microbiology 40, 163-165.

Saracino, L., Violet, M., Boxer, D. H. \& Giordano, G. (1986). Activation in vitro of respiratory nitrate reductase of Escherichia coli K-12 grown in the presence of tungstate. European Journal of Biochemistry 158, 483-490.

Seki-Chiba, S. \& Ishimoto, M. (1977). Studies on nitrate reductase of Closiridium perfringens. Journal of Biochemistry 82, 1663-1671.

Shen, T.-C., Ramados, C. S. \& Vennesland, B. (1982). Effect of reduced pyridine nucleotides and tungstate on the in vitro insertion of molybdenum into demolybdo-nitrate reductase of Chlorella vulgaris. Biochimica et Biophysica Acta 704, 227-234.

Stanier, G. \& Davies, A. (1981). Effects of the antibiotic monensin and an inhibitor of methanogenesis on in vitro continuous rumen fermentations. British Journal of Nutrition 45, 567-578. 
Tachiki, T. \& Nason, A. (1983). Preparation and properties of apoenzyme of nitrate reductases from wild-type and nit-3 mutants of Neurospora crassa. Biochimca et Biophysica Acta 744, 16-22.

Takahashi, J. (1983). Effect of intra-pregastric administration of nitrite on erythrocyte GSH and GSSG contents of the male golden hamster (Mesocricetus auratus). Comparative Biochemistry and Physiology 76B, 1-4.

Tillman, A. D., Sheriha, G. M. \& Sirny, R. J. (1965). Nitrate reduction studies with sheep. Journal of Animal Science 24, 1140-1146. 